J. Lake Sci. (湖泊科学) , 2013, 25(6): 799-808

http: //www. jlakes. org. E-mail : jlakes@niglas.ac.cn

(C) 2013 by Journal of Lake Sciences

\title{
2000 年以来天目湖流域茶园分布变化及趋势模拟”
}

\author{
习亚芹 ${ }^{1,2}$, 韩 莹 $^{1,2}$, 李兆富 ${ }^{3}$ \\ (1: 中国科学院南京地理与湖泊研究所湖泊与环境国家重点实验室,南京 210008) \\ (2: 中国科学院大学, 北京 100049) \\ (3: 南京农业大学资源与环境科学学院,南京 210095)
}

摘 要: 土地利用/土地覆被变化 ( LUCC) 与区域的可持续发展密切相关,分析土地利用变化及其空间变量的关系,建立 模拟模型来认识和揭示土地利用变化的特征和时空分布规律, 为未来规划和政策的制定提供支持是 LUCC 研究的重点问 题之一. 本研究以太湖流域上游典型丘陵山区茶园开发作为重点研究对象,结合中高分辨率遥感影像信息、1:50000 国家 标准地形图数据和野外土壤采集分析数据获取 2000 年以来茶园及其它土地利用信息、研究区地形地貌数据和土壤数据, 通过对 2000 年以来茶园及其新开茶园的区位分布分析,发现茶园的变化呈现快速增长的趋势, 11 年研究区茶园面积扩 大了 5 倍,其中一半以上的面积是最后 3 年增长的; 茶园在流域上不同分区的分布差异比较大,这些差异与分区自然条 件、区位条件和开发条件有一定关系. 根据 Cramer V 卡方检验结果值,比较不同的茶园区位影响因子对茶园分布的影响 力,确定高程、坡度、水库、河流、村落、主干道路和茶园规模对茶园区位影响比较显著. 用茶园区位影响显著性的 7 个因子 通过迭代优化建立 MLP 神经网络模型, 对研究区的未来茶园的分布区位进行模拟, 并且用已开发茶园对模型进行验证, 达到 $84 \%$ 的区位预测精度. 基于模型用现有茶园开发模式、2000 年左右茶园开发模式和折中模式 3 种情景模拟未来茶园 的分布,发现按现有的茶园开发速度,2020 年茶园总面积将达到流域总面积的 $1 / 4$,任何一种情景都改变不了茶园在重要 功能区的增长趋势, 因此迫切需要政府采取相应的措施对茶园面积的增长和区位的分布进行控制.

关键词: 天目湖流域; 土地利用;茶园; 时空特征; 神经网络模型; 情景预测

\section{Spatio-temporal change of tea plantation since 2000 and model-based prediction in the Tianmuhu Reservoir watershed}

DIAO Yaqin ${ }^{1,2}$, HAN Ying ${ }^{1,2} \&$ LI Zhaofu ${ }^{3}$

(1: State Key Laboratory of Lake Science and Environment, Nanjing Institute of Geography and Limnology , Chinese Academy of Sciences, Nanjing 210008 , P. R. China)

(2: University of Chinese Academy of Sciences, Beijing 100049, P. R. China)

(3: Institute of Resource and Environment of Nanjing Agricultural University, Nanjing 210095, P. R. China)

Abstract : Land use/cover change ( LUCC) is closely related to regional sustainable development. It is an important issue in LUCC investigations to analyze the relationship between land use change and its influencing variables on spatial scale, to reveal the change in land use and its spatio-temporal distribution characteristics by developing a simulation model, and to support the future decisionmaking. This study took the Tianmuhu Reservoir watershed, the land use of which has been changed rapidly with the dominant cash crop of tea plantation in upstream of the Lake Taihu basin, as the study area. Interpretation of the high-resolution remote sensing imagery provided the data of tea plantation and other land uses since 2000. Topography and soil data were obtained from the 1:50000 scale national standard relief map and soil sampling with laboratory analysis, respectively. Analyses of the spatial distribution and area change of existing and newly-exploited tea plantation since 2000 revealed that the tea plantation area was in a rapidly increasing trend. The tea plantation area expanded 5 times in the past 11 years and half of those increased in the last 3 years.

* 国家自然科学基金重点项目 (41030745)、中国科学院重点部署项目 (KZZD-EW-10-04)、中国科学院南京地理与湖 泊研究所“一三五”重点布局项目 (NIGLAS2012135005)、江苏省自然科学基金项目 (SBK200920953) 和溧阳市沙河 水库管理处科研项目联合资助. 2013-03-19 收稿;2013-04-28 收修改稿. 刀亚芹,女,1987 年生,硕士研究生; E-mail: mobing0503@163.com. 
There was a big difference in the spatial distribution of tea plantation among sub-regions, because of their different natural backgrounds, geographical factors and suitability conditions for tea plantation. The results of Cramer V chi-square test showed that elevation, slope, reservoirs, rivers, villages, roads and the scale of tea garden were the most significant factors for the spatial distribution of tea plantation. The MLP neural network model for the prediction of tea planation was developed through iterations based on the seven significant influencing factors. It was validated using the area of existing tea plantation, the performance of which reached to $84 \%$. Application of the model in predicting the future spatial distribution of tea plantation under current, 2000 , and the compromised tea-exploitation mode displayed that the area of tea plantation in 2020 will account for 1/4 of the watershed area if it is exploited following the current pace. None of the three scenarios could change the growing trend of tea plantation. Therefore, it is urgent to push the local government to take corresponding strategies and measures to control the increasing area of tea planation and adjust its spatial distributions

Keywords: Tianmuhu Reservoir watershed; land use; tea plantation; spatio-temporal distribution; ANN model; scenario prediction

我国东南湿润区地形以丘陵山区为主 ${ }^{[1]}$, 水热组合条件优越 ${ }^{[2]}$, 植被覆盖度高, 在区域供水和生态安全 方面发挥着重要的功能. 近年来随着社会经济的发展,过快的城市化使得耕地大幅度减少, 人地关系日益紧 张. 地方政府为了保证农业持续发展,纷纷出台引导和鼓励丘陵山区农业开发的政策,加大丘陵山区综合农 业的开发并成为该区土地利用变化的主要趋势. 丘陵地区地形坡度大, 大面积的开发造成山区地表森林覆 盖度减小、水土流失加剧, 自然生态受到破坏, 严重危及到该区的供水和生态安全.

土地利用 $/$ 覆被变化 ( LUCC) 是人类作用于自然界的最直接表现 ${ }^{[3-4]}$, 是全球变化的主要组成部分和主 要原因,与可持续发展密切相关 ${ }^{[4-6]}$, 自 1995 年 IGBP 和 IHDP 两大国际组织共同拟定并发表了《土地利用与 土地覆被变化科学研究计划》以后, LUCG 日益受到国际组织和世界各国的普遍关注, 成为国际全球变化研 究的重要领域和前沿问题 ${ }^{[7-8]}$. 我国也进行了许多相关的 LUCC 研究 ${ }^{[9-12]}$, 但是以往的土地利用/土地覆被变 化关注较多的是城市扩展问题, 已经建立多个时间段土地利用/土地覆被变化信息, 研究城镇的时空变化特 征, 并揭示人口及其经济增长对城市化的驱动机制和产生的影响 ${ }^{[13-15]}$. 由于丘陵山区林地向茶果园的土地 利用转换方式较少受到关注, 同时因丘陵山区斑块破碎度高, 目前土地利用变化采用的中等分辨率遥感数 据难以提取其变化信息 ${ }^{[16]}$, 至今针对丘陵山区茶果园开发驱动的土地利用变化尚缺乏系统分析.

本研究以太湖流域上游的天目湖丘陵山区作为代表性区域, 结合近年来高分辨率遥感信息, 解译获取 研究区 2000 年以来 6 个时段土地利用序列信息,重点分析该流域茶园开发的时空变化特征; 然后综合应用 GIS 空间分析、Cramer V 卡方检验等方法, 揭示天目湖地区茶园分布变化的驱动机制, 最后建立天目湖流域 的茶园开发 MLP 模拟模型进行情景模拟, 分析其未来可能的趋势, 为理解东南丘陵山区土地利用变化的机 制提供案例.

\section{1 研究区概况}

天目湖流域位于江苏溧阳和安徽广德、郎溪境内, 为太湖上游丘陵山区, 属天目山余脉, 地貌类型多样, 以低山丘陵为主, 高程主要分布在 $2 \sim 541 \mathrm{~m}$, 流域面积 $246 \mathrm{~km}^{2}$, 拥有沙河水库和大溪水库两座国家级大型 水库,流域面积分别为 154 和 $92 \mathrm{~km}^{2}$. 该流域的主要土地利用/覆被类型包括:农田、林地、茶园、水体等. 依 据 2011 年天目湖流域的土地利用解译数据统计, 林地是天目湖流域最主要的土地用地类型, 面积占 $37.7 \%$; 茶园是丘陵最重要的农业开发类型, 面积位居第三, 为 $26.9 \mathrm{~km}^{2}$, 占流域总面积的 $10.9 \%$. 地带性土壤为黄 棕壤, 微酸性, 保水保肥性差, 易被水冲刷导致水土流失, 山间谷地分布有渗育型水稻土. 天目湖地区是东南 湿润区丘陵山区农业综合开发的代表性区域,集供水、旅游和农业于一体. 天目湖水库 ( 沙河水库与大溪水 库) 是我国首批 AAAA 风景区, 农业以发展名优茶业为主, 承担了溧阳市 60 万人口供水, 然而近年来的发展 已经危机到区域生态与供水安全.

\section{2 研究数据和方法}

\section{1 技术框架}

本研究首先综合高分辨率遥感影像数据、1:50000 国家标准地形图数据和植被覆盖及野外考察资料, 通 
过标准化处理、解译、GIS 空间分析等建立土地利用变化序列数据库和土地利用变化影响因素的数据库(包 括高程、坡度、水库距离、道路距离、村落距离、河流距离、新老茶园距离、总氮、总磷、有机质). 其次通过土地 利用变化数据序列及其影响因素的叠加与统计,分析 2000 年以来天目湖地区的土地利用时间变化特征和 空间分布特征. 运用 Cramer V 卡方检验的方法,评价不同因素对茶园分布的影响程度,并篮选出土地利用分 布的关键影响因素, 基于关键影响因素和土地利用变化特征, 建立茶园开发 MLP 神经网络模拟模型, 并用已 有的茶园增长数据对茶园开发 MLP 神经网络模拟模型的预测结果进行验证. 最后基于模拟模型, 设置茶园 开发的不同情景,模拟未来茶园变化的趋势 (图 1).

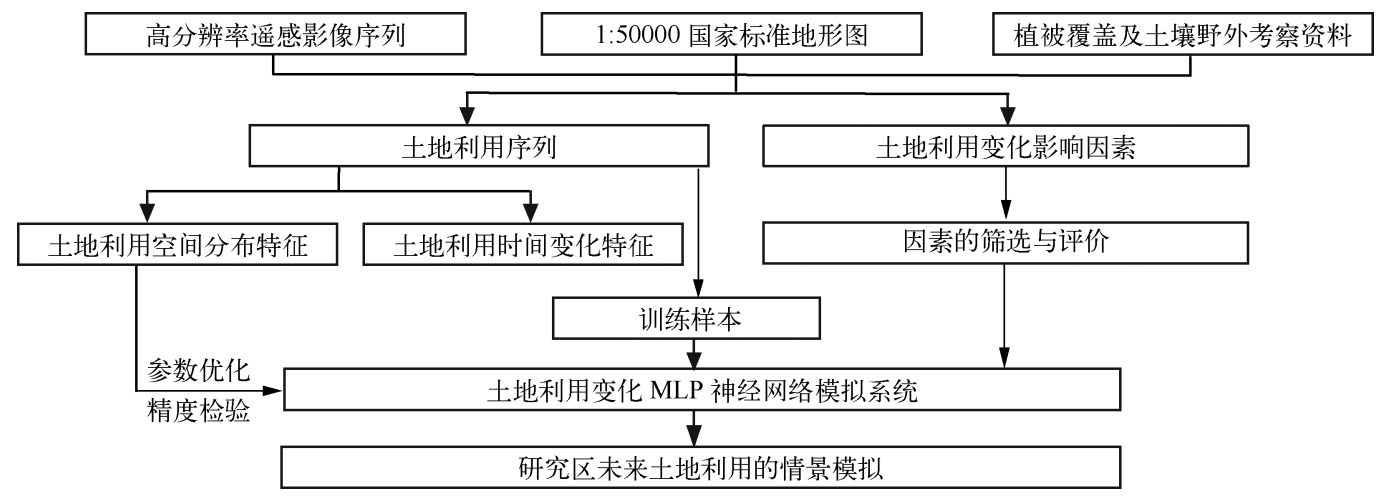

图 1 土地利用变化时空变化分析及其模拟模型建立技术流程

Fig. 1 The flow chart of analysis in land use space-time change and prediction model

\section{2 数据基础}

依据茶园的分布特点以及不同时期数据的可比性, 解译不同年份土地利用尽量选择空间分辨率接近的 数据源, 通过 $\operatorname{Spot5}(2002,10 \mathrm{~m}) 、 \operatorname{ALOS}(2008,2010,10 \mathrm{~m}) 、 \operatorname{RapidEye}(2011,5 \mathrm{~m})$ 和 $\operatorname{ETM}(2000,2005,15 \mathrm{~m})$ 遥感解译,共获取 6 个时期的数据. 土地利用类型参考国家标准土地利用分类系统并结合该区的实际情况,主 要分为林地、耕地、茶园、水体、草地、建设用地、裸地、河湖湿地、退耕地. 高程和坡度数据采用 1:50000 $25 \mathrm{~m}$ 国家标准地形图通过地形分析获取. 水库、河流、道路、村落信息采用国家 1:50000 标准地形图数字化,并通 过中高分辨率遥感影像纠正获取,与以上要素的距离采用 GIS 的邻距分析获取. 土壤数据以 1:200000 土壤 类型分布图为基础,针对主要土地利用类型和土壤类型采集 60 个土壤样品进行实验室分析,建立该区土壤 速效氮、速效磷和有机质分布 3 个影响因子的最新数据. 茶园距离变量主要是对高分辨率遥感影像提取的 现有茶园分布进行邻距分析获取,用于茶园规模扩张的表达.

\section{3 茶园分布影响因素评价}

2.3.1 Cramer V 卡方检验 为了准确地评价影响茶园分布的关键性因素, 本研究用 Cramer V 卡方检验来定 量化茶园在空间变量上分布概率的差异性. 卡方检验根本思想就是在于比较理论频数和实际频数的吻合程 度或拟合优度问题 ${ }^{[16]}$. Cramer V 卡方检验的值表达为:

$$
\text { Cramer } \mathrm{V}=\sqrt{\frac{\chi^{2}}{n \cdot \min [(r-1),(s-1)]}}
$$

式中, $\chi^{2}$ 表示卡方检验结果, $r 、 s$ 分别表示行、列数, $n$ 为样本数 ${ }^{[17]}$.

评价因子 Cramer V 值越大, 说明该评价因子空间差异与茶园分布的关联性越大; 反之, Cramer V 指数越 小, 说明评价因子空间差异与茶园分布的关联性越小. 一般情况下, Cramer V 指数在 0.4 以上时, 空间变量 对茶园分布有重要的影响; Cramer V 指数在 $0.2 \sim 0.4$ 时, 影响因子对茶园的分布有影响; Cramer V 指数小 于 0.2 时, 影响因子对茶园的分布影响可以忽略 ${ }^{[18]}$.

2.3.2 影响因素及其评价结果 研究在总结分析典型用地类型茶园种植相关文献 ${ }^{[19-22]}$ 及实地访谈的基础 上,重点从茶园种植的自然条件和具备的开发条件两个方面选择合适的区位影响指标, 考虑地形地貌指标、 
表 1 茶园分布影响因子和空间变量表达及其评价结果

Tab. 1 The tea plantation distribution relation factors and its Cramer V chi-square test results

\begin{tabular}{cllc}
\hline 影响条件 & 因素指标类型 & 指标空间变量表达 & Cramer V 卡方检验值 \\
\hline 自然条件 & 地形地貌指标 & 高程 & 0.587 \\
& & 坡度 & 0.403 \\
& 土壤指标 & 速效氮 & 0.155 \\
& & 速效磷 & 0.149 \\
& & 有机质 & 0.123 \\
开发条件 & 区位指标 & 到河流的距离 & 0.227 \\
& 到水库距离 & 0.420 \\
& 达性指标 & 到主要道路距离 & 0.254 \\
& 规模指标 & 到主要村落的距离 & 0.217 \\
& 到已开发茶园的距离 & 0.313 \\
\hline
\end{tabular}

土壤指标、区位指标、可达性指标和 规模指标等共 10 个影响因子 (表 1) 分析茶园区位分布.

从 10 个因子的 Cramer V 卡方 检验结果值看, 地形地貌直接决定 茶园能否种植, 是茶园开发自然适 宜性的控制性因子, 与地形地貌密 切相关的坡度和高程卡方值均达到 0.4 以上, 尤其是坡度, 卡方值达到 0.587. 水库距离对茶园分布的影响 力仅次于坡度因子, 卡方值达到 0.420 , 因为离水库的距离会影响到 茶园的开发价值和观光农业价值, 并且水库型流域的自然和人文要素 都随着距水库的距离呈现出规律性 的变化. 水库距离决定茶园开发的价值和难易程度, 是影响茶园开发的关键区位因子和综合因子. 距茶园、 道路、村落和河流的距离 4 个适宜性评价因子的卡方检验值均达到 0.2 以上, 是影响茶园开发条件的重要适 应性因子. 土壤 3 个指标对茶园分布卡方检验值均在 0.2 以下, 说明土壤因素不是茶园开发的控制性因素, 这主要因为现代茶园开发通过施肥改变土壤的养分条件, 养分主要靠外界输人进行补充 ${ }^{[23]}$. 笁选卡方检验 值 0.2 以上的因子作为茶园影响重要的因子, 因此坡度, 高程, 到水库、河流、主要道路、主要村落和已开发 茶园的距离是影响茶园分布的关键因素.

\section{4 茶园变化 MLP 神经网络模拟模型}

土地利用过程变化受到众多地理要素的影响, 神经网络模拟模型基于较强的自学习能力优势, 自动基 于已有土地利用变化的模式去推理未来土地利用变化的趋势, 实现多个变量影响下输出结果的精确化和定 量化过程, 减少确定权重和影响因子集成的主观性. 由于神经网络模拟人脑的思维过程处理各种关系, 尤其 是错综复杂的地理空间关系, 在国内外都得到广泛的应用 ${ }^{[24-25]}$.

为了建立天目湖茶园 MLP 模拟模型, 根据前面 Cramer V 卡方检验的评价结果, 篮选出 7 个重要影响因 素: 高程、坡度、河流、水库、主要道路、村落、茶园规模. 在 IDRISI 地理信息系统软件环境中,将 7 个关键影响 因素作为神经网络的输人信号, 将现状茶园和近期变化作为茶园空间分布的训练样本, 设定训练的精度或 者误差范围, 通过 MLP 神经网络模型多次迭代使模型结果达到最佳, 建立天目湖地区茶园开发的 MLP 模拟 模型, 模型结果将不同区域的林地开发为茶园的可能性量化在 $0 \sim 1$ 标准上. 将实际增长的茶园用 MLP 茶园 开发模拟模型分散在不同的区域上,然后用实际区位对预测区位进行验证.

神经网络模拟模型是基于现在土地利用变化的模式去推理未来土地利用变化的趋势, 在预测未来时期 土地利用变化时, 模拟结果的可靠性与预测时段和训练时段土地利用的政策是否发生较大变化有关, 只有 这样才能保证训练参数能够揭示未来的土地利用变化特征. 本研究采用 2008-2010 年作为训练样本, 因为 这一段时间农业开发中水利设施和道路建设给以补贴等农业开发鼓励政策稳定实施, 与现在政策比较接 近, 同时较短的时段内政策变化不大, 训练参数用于模拟 2011 年的变化, 并通过 2011 年真实的变化检验模 型模拟的效果, 模拟精度评价采用公式 2 .

$$
\text { 模拟精度 }=\sum 1 \text { 分区模拟像元总数 }- \text { 分区实际像元总数 } \mid / \text { 增长像元总数 }
$$

模型精度采用分区精度检验的方法代替像元一一对应的检验方式, 因为茶园开发在流域的不同部位 对流域生态及水环境产生的影响有较大差异, 如上游地区是水源区, 茶园开发对水源涵养功能有很大影 响, 而河口区对水质有较强的净化作用, 开发后对水质影响显著, 因此预测茶园分布格局的变化比局部像 元变化更重要. 分区采用基于土地利用变化的综合因素分区评估进行的分区结果, 定量化分析茶园在这 些区域上的分布特征. 结果显示, 模拟结果与 2011 年实际茶园开发在各个分区的相对分布大小趋势具有高 
度的一致性,对于茶园增长的平均模拟精度达到 $84.0 \%$,即使模拟差异最大的沙河水库西岸岸坡精度也在 $75 \%$ 以上.

\section{3 结果与分析}

\section{1 土地利用时间变化特征}

3.1.1 土地利用总体变化特征 茶园开发对林地的占用是研究区的主要土地利用转换类型. 采用天目湖流 域 2002 年和 2011 年的土地利用类型变化面积进行矩阵统计分析 (表 2),发现面积减少的用地类型主要是 林地和农田, 分别为 21.3 和 $11.9 \mathrm{~km}^{2}$; 面积增多的用地类型主要是茶园、退耕地、裸地和建设用地, 分别为 18.3、6.8、3.5 和 $2.5 \mathrm{~km}^{2}$. 转换类型主要是林地向茶园、建设用地及裸地的转换,农田还林 (草) 和建设用地 的转换. 茶园增长主要是占用林地类型, 平均每年的占用面积为 $2.0 \mathrm{~km}^{2}$, 即每年约 $1.6 \%$ 的林地转化为 茶园。

表 2 天目湖地区 2002 年和 2011 年土地利用变化转换矩阵 $\left(\mathrm{km}^{2}\right)$

Tab. 2 The landuse change matrix in 2002 and 2011 in Tianmuhu Reservoir region

\begin{tabular}{|c|c|c|c|c|c|c|c|c|c|}
\hline & \multicolumn{8}{|c|}{2002 年 } \\
\hline & & 农田 & 水体 & 林地 & 草地 & 建设用地 & 湿地 & 裸地 & 茶园 \\
\hline \multirow[t]{9}{*}{2011 年 } & 农田 & 55.5 & 0 & 0 & 0 & 0 & 0 & 0.4 & 0 \\
\hline & 水体 & 0.3 & 26.3 & 0.3 & 0 & 0 & 0 & 0.1 & 0 \\
\hline & 林地 & 0.9 & 0 & 105.7 & 0 & 0 & 0.1 & 0 & 0 \\
\hline & 草地 & 0.9 & 0.1 & 0.1 & 2.2 & 0 & 0 & 0 & 0 \\
\hline & 建设用地 & 1.6 & 0 & 0.8 & 0 & 8.4 & 0 & 0 & 0.1 \\
\hline & 湿地 & 0 & 0 & 0 & 0 & 0 & 4.7 & 0 & 0 \\
\hline & 裸地 & 0.9 & 0 & 2.6 & 0 & 0 & 0 & 0.4 & 0 \\
\hline & 退耕地 & 6.7 & 0.2 & 0 & 0 & 0 & 0 & 0 & 0 \\
\hline & 茶园 & 0.7 & 0 & 17.5 & 0 & 0 & 0 & 0 & 8.3 \\
\hline
\end{tabular}

3.1 .2 茶园时间变化特征 为了进一步分析茶园逐年的变化速率, 对 2000 年以来其开发面积进行统计分 析, 发现其呈现快速增长的趋势 (图 2). 11 年间流域茶园的面积迅速由 $6.2 \mathrm{~km}^{2}$ 增长到 $26.5 \mathrm{~km}^{2}$, 平均每年 增长流域面积的 $0.75 \% .2005$ 年以前, 加速增长的趋势尚且不明显, 5 年时间茶园面积从 $6.2 \mathrm{~km}^{2}$ 增长到 $10.1 \mathrm{~km}^{2} .2005$ 年以后,当地政府鼓励茶园的开发种植,企业投资规模化开发茶园,不仅使得茶园开发的速 度增加,而且茶园的规模也迅速增大, 2005 年以前茶园的平均规模由 2005 年的 $4.5 \mathrm{hm}^{2}$ 增长到 2008 年的 $6.6 \mathrm{hm}^{2}$. 尤其是 2008 年以后研究区的茶园开发速度平均达到 $4.1 \mathrm{~km}^{2} / \mathrm{a}$, 占流域总面积的 $1.67 \%$, 将近 2005 年以前的 6 倍, 超过 20 世纪末以来太湖流域城镇化的发展速率 $(0.9 \%)^{[26]}$, 由此可见茶园长期按此速 率增长,天目湖丘陵山区自然林地将丧失殆尽.

\section{2 茶园空间分布特征}

茶园在研究区的空间分布及其变化上均有显著的差异,这些差异可能受地形条件、区位条件和可达性 条件影响. 高程和坡度直接影响到茶园种植的开发成本与开发效益, 因为高程高、坡度陡的区域不仅水热条 件不适宜茶园的生长, 而且大型现代化设备难以进人,茶园管理所需的人力、物质资源难以到达. 为了验证 地形条件对茶园分布的影响,本研究对茶园的地形和坡度进行分析 (图 3a、b), 发现茶园在两者分布上均比 较集中. 天目湖地区高程范围为 $0 \sim 531 \mathrm{~m}$, 坡度范围 $0 \sim 52^{\circ}$. 根据统计, $0 \sim 90 \mathrm{~m}$ 高程内茶园分布最多,增长 最快,各个时期都集中了研究区 $90 \%$ 左右的茶园; 尤其是 $30 \sim 60 \mathrm{~m}$ 高程,各时期茶园面积都达到研究区总 面积的 $40 \% ; 150 \mathrm{~m}$ 以上高程范围内茶园分布不足 $2 \%$. 在坡度上,茶园坡度一般不超过 $25^{\circ}, 80 \%$ 的茶园集 中在 $0 \sim 15^{\circ}$ 坡度,在整体上随着坡度的增加茶园面积呈现出减少的趋势; 但是由于坡度太低、土壤透水性不 好,多宜开发为农田,所以就开发密度而言, $0 \sim 5^{\circ}$ 坡度的开发密度低于 $5 \sim 10^{\circ}$ 和 $10 \sim 15^{\circ}$, 分别是 2 个密集 区的 $1 / 4$ 和 $1 / 2$. 由此可见, 高程和坡度是影响茶园分布差异的重要条件. 

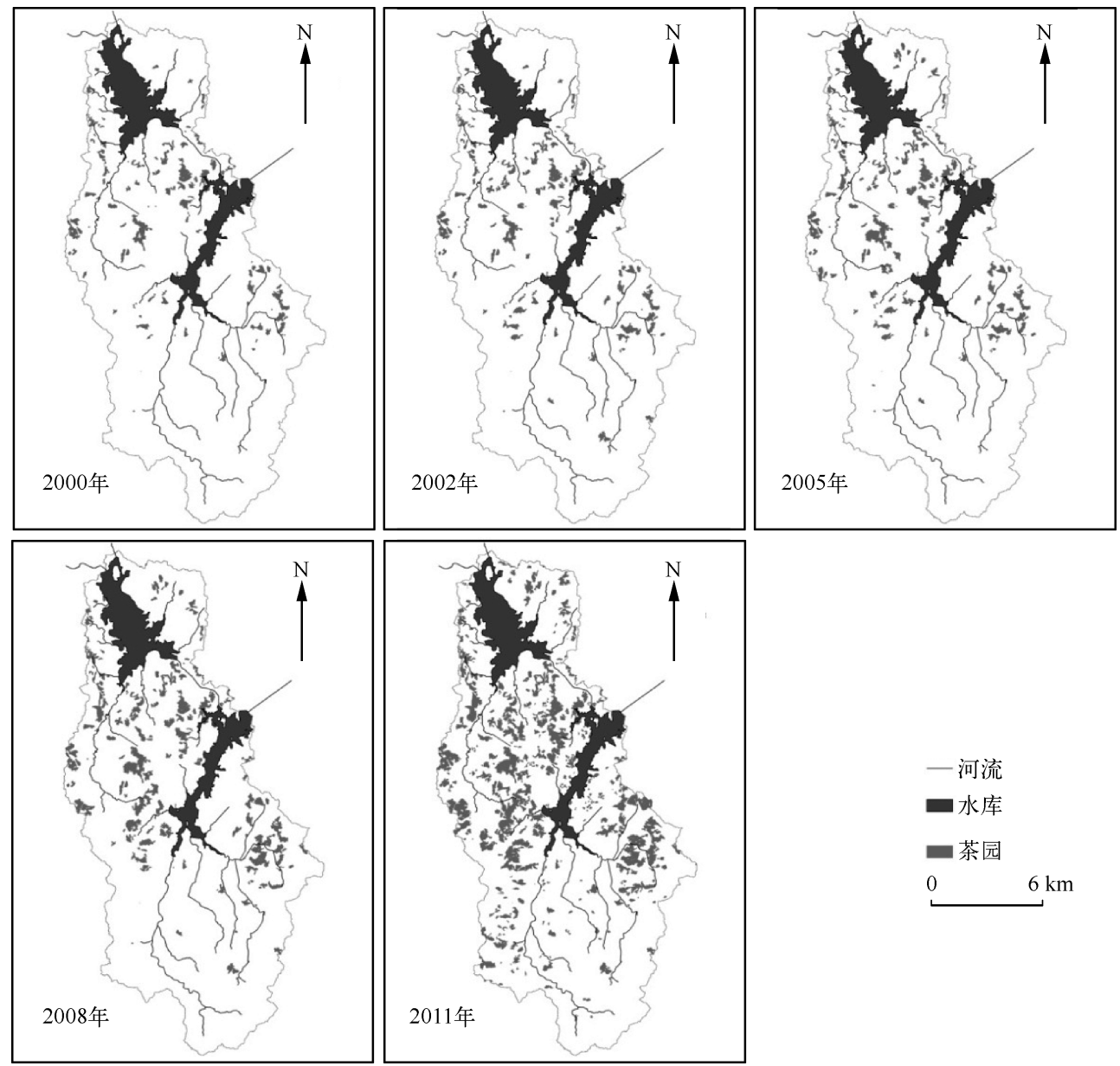

图 2 天目湖地区不同时期茶园开发空间分布

Fig. 2 The tea plantation space distribution at different times in Tianmuhu Reservoir region

在天目湖地区, 沙河水库和大溪水库发挥着重要的供水和旅游的功能, 水库附近相对上游地区交通条 件较好, 居民点分布多, 而且茶园开发兼具旅游观光价值. 对流域内距水库不同距离的茶园分布进行分析 (图 3c), 发现各个时期茶园整体上都具有向水库趋近的趋势. $1 \sim 2 \mathrm{~km}$ 距离处, 条件较好的山坡分布比较多, 茶园开发面积与开发密度均最高, 2011 年有 $40.0 \%$ 的茶园分布在该分区内; 其次是 $2 \sim 3 \mathrm{~km}$ 水库距离分区, 茶 园面积比例为 $21.5 \%$. 水库周边应水源保护需求和水位变化淹没危机, 水库 $1 \mathrm{~km}$ 距离范围内分布相对少些; 水库 $3 \mathrm{~km}$ 距离以外近年随着流域上交通条件的改善和茶园开发技术的进步, 茶园开发向流域上游扩张.

因此,综合地形条件、区位条件和可达性条件, 本研究运用 DEM 数据通过 ARCGIS 的插件 Arc Hydro 的 水文流域划分,将整个流域按照与两大水库的上下游关系,划分为 11 个流域分区: 区域 1 : 大溪水库西岸临 湖岸坡; 区域 2 : 大溪水库东岸临湖岸坡; 区域 3 : 大溪水库河口区; 区域 4 : 大溪水库中下游山区; 区域 5 : 大溪 水库上游水源涵养区; 区域 6 : 沙河水库西岸临湖岸坡; 区域 7 : 沙河水库东岸临湖岸坡; 区域 8 : 沙河水库河 口区; 区域 9 : 沙河水库中下游西部山区; 区域 10 : 沙河水库中下游东部山区; 区域 11 : 沙河水库上游水源涵 养区(图 4). 对茶园在 11 个分区上的分布进行统计发现, 大溪水库中下游山区、沙河水库西岸临湖岸坡、沙 河水库中下游东部山区 3 个分区内集中了流域 70\% 左右的茶园面积. 这 3 个区域地形较缓、周围大型居民 区集中,道路网密集, 是流域上社会经济基础设施比较完善的区域. 流域的上游地区为区域的水源涵养区, 植被覆盖度高, 茶园开发的成本高, 并且区域的社会经济发展落后, 道路分布稀少, 茶园开发面积比较少, 茶 园分布比例在 $10 \%$ 以下. 2008 年以后沙河水库中下游西部山区的面积增长加快, 迅速成为天目湖流域茶园 
开发的重点区域,因为大规模的企业经营占 据水库周边优势地理位置,在经济利益的驱 使下,许多个体承包或者小型的企业将开发 转移到沙河水库中下游西部山区广阔的丘 陵山地地区.

\section{3 茶园分布变化趋势模拟}

天目湖同时承载着供水、旅游和农业发 展的重任,在未来可能出现开发与水源地生 态保护的冲突,如果能够了解未来土地利用 的可能变化,就可能提前制定相关限制政策 避免不利的土地利用变化发生. 因此,预测 茶园未来的发展趋势具有重要的意义. 考虑 到未来土地利用政策有很大的不确定性,本 研究依据不同情景茶园增加量, 选择 3 种情 景模拟 2020 年茶园在空间区位上的分布 (图 5): 情景 1 延续现有变化: 即茶园增长 速率 $4.1 \mathrm{~km}^{2} / \mathrm{a}$, 到 2020 年天目湖地区的茶 园总面积将达到 $63.4 \mathrm{~km}^{2}$, 占流域总面积的 $1 / 4$; 情景 22000 年左右未出台鼓励政策时 期的变化:政府采用茶园开发控制政策,茶 园的增长速率减缓到 $0.7 \mathrm{~km}^{2} / \mathrm{a}$, 到 2020 年 流域上的茶园总面积约为 $32.8 \mathrm{~km}^{2}$; 情景 3 两者折中开发: 茶园的增长为情景 1 与情景 2 的平均值, 即 2020 年流域茶园总面积为 $48.6 \mathrm{~km}^{2}$.

水库周边地区和上游水源涵养区茶园 的分布情况对区域整体生态功能的维护和 水库水质水量的保护具有重要的意义, 因此 重点分析 3 种情景下这些区域茶园开发对 区域林地占用的面积 (表 3 ). 沙河水库和大 溪水库水源涵养区在 3 种情景中林地覆盖 度的降低比例分别为 $21 \% 、 4 \% 、 10 \%$ 和
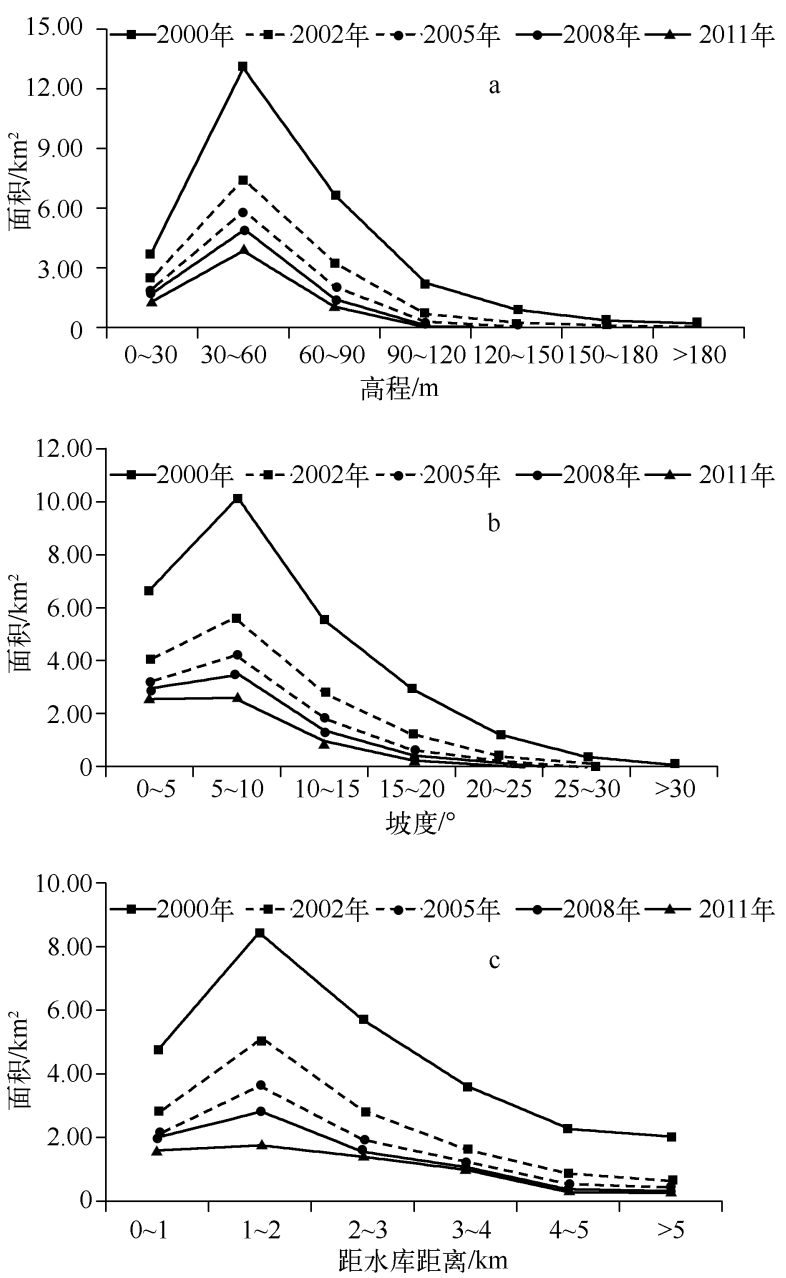

图 32000 年以来天目湖流域茶园不同高程 (a)、 坡度 $(\mathrm{b})$ 和水库距离 $(\mathrm{c})$ 的分布面积变化

Fig. 3 The area distribution of tea plantations in different elevation(a), slopes(b) and the distances

from reservoirs(c) in Tianmuhu Reservoir area since 2000

$19 \% 、 2 \% 、 7 \%$; 可见情景 1 模式下水源涵养区的林地覆盖度下降比较快,可能会威胁到整个流域的水源供 给问题; 情景 2 林地覆盖率降低比较缓慢,仅为情景 1 过程中的 $1 / 5$ 和 $1 / 8.5$, 但是这种模式林地覆盖度仍 然呈现减少的趋势. 两水库临湖地带茶园在 3 种情景中增加 $0.5 \sim 2.0$ 倍, 情景 1 临湖岸坡地带茶园的增长 速率达到情景 2 的 4 倍和 2 倍, 茶园快速增长可能会导致营养物质人湖量增多,影响水库的水质. 情景 1 模式茶园增长快,破坏区域生态多样性,可能会威胁到区域的水量供给和水质安全,茶园开发应当受到控 制. 情景 2 和情景 3 模式下,虽然茶园的开发速率较情景 1 有所减慢,短期内的破坏不及情景 1 , 但是从长 期来看,不能改变茶园开发所带来的水源地破坏趋势. 在未来茶园开发的控制管理过程中,制定政策重新分 配茶园发展的区域分布,对具有重要生态功能价值的区域重点保护十分必要.

\section{4 结论}

茶园是天目湖流域丘陵山区的主要开发类型,面积占整个流域的 10.7\% (2011 年数据). 2000-2011 年流 域茶园开发总面积由 $6.2 \mathrm{~km}^{2}$ 增长至 $26.5 \mathrm{~km}^{2} ; 11$ 年茶园的平均增长速率为 $1.8 \mathrm{~km}^{2} / \mathrm{a}$, 约为流域总面积的 

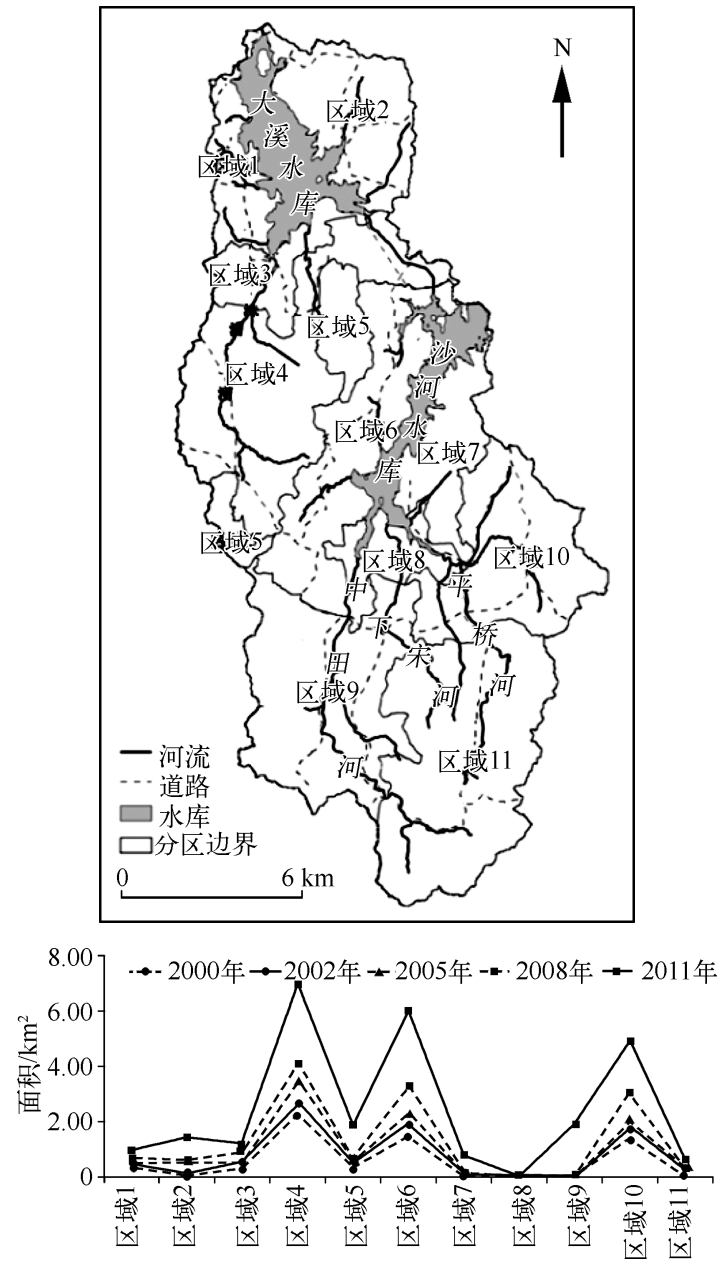

图 4 天目湖水文流域分区和 2000 年以来 茶园在不同分区内的分布变化

Fig. 4 The hydrological basin areas and tea plantation area distribution of them in Tianmuhu Resevoir region since 2000
$0.75 \% .2000$ 年以来茶园开发速度呈现出快速增长 的趋势, 尤其是 2008 年以后在政府鼓励和市场的双 重刺激下, 茶园开发速率增长为 2008 年以前的 3.7 倍,每年流域面积的 $1.67 \%$ 被开发为茶园.

茶园在流域上的空间分布存在很大的差异性, 而且由于茶园开发规模化效益的影响, 茶园集中的 区域增长相对较快. 在天目湖地区的 11 个水文分 区中, 大溪水库西部临湖岸坡、沙河水库西岸临湖 岸坡和沙河水库中下游东部山区 3 个区域集中了 整个流域 $70 \%$ 的茶园. 这些差异性与茶园开发的地 形条件、区位条件和开发条件有关. 高程高、坡度大 会增加开发的成本、降低茶园的效益, 因此 $90 \%$ 以 上的茶园分布在 $90 \mathrm{~m}$ 高程范围内, 坡度一般不超 过 $25^{\circ}$. 由于区域社会经济发展活动围绕水库进行, 茶园分布在整体上有靠近水库分布的趋势.

综合茶园开发的自然条件和区位、规模等开发 条件,篮选出影响茶园分布的 7 个关键因素: 高程、 坡度、水库、河流、道路、村落和茶园规模, 建立天目 湖地区的茶园开发 MLP 神经网络模拟模型, 区位 预测精度达到 $84 \%$. 这种模型能够反映过去研究区 茶园开发的模式, 具有预测未来茶园开发的空间分 布的能力, 可以用来模拟天目湖地区今后茶园开发 的空间分布状况.

按照现有茶园开发变化、2000 年左右政府未出 台鼓励政策时期的茶园变化和折中变化这 3 种发展 情景来模拟 2020 年茶园开发. 按照现有的开发模 式, 即 $4.1 \mathrm{~km}^{2} / \mathrm{a}, 2020$ 年天目湖流域茶园面积将达 到 $63.4 \mathrm{~km}^{2}$, 现有林地的 $1 / 3$ 将被开发为茶园, 流 域面积的 $1 / 4$ 以上将分布为茶园类型; 水源涵养区 林地的覆盖度都将降低 $20 \%$ 左右, 水库临湖岸坡茶 园面积增长为现在的 3 倍和 2 倍; 未出台政策以前 的发展模式在很大程度上能够减慢水源涵养林地 的占用速率, 但是无法改变占用的趋势, 因此未来的茶园开发管理政策必须从面积的限制和格局分布的调 控两方面采取措施进行控制管理.

表 3 不同预测情景下 2020 年林地在主要功能分区内的分布

Tab. 3 The distribution of forest in the main watershed function areas under different prediction scenarios in 2020

\begin{tabular}{|c|c|c|c|c|c|c|c|c|}
\hline \multirow{2}{*}{ 功能分区 } & \multicolumn{2}{|c|}{ 现有林地 } & \multicolumn{2}{|c|}{ 情景 1} & \multicolumn{2}{|c|}{ 情景 2} & \multicolumn{2}{|c|}{ 情景 3} \\
\hline & 面积 $/ \mathrm{km}^{2}$ & 比例 $/ \%$ & 面积 $/ \mathrm{km}^{2}$ & 比例 $/ \%$ & 面积 $/ \mathrm{km}^{2}$ & 比例 $/ \%$ & 面积 $/ \mathrm{km}^{2}$ & 比例 $/ \%$ \\
\hline 全流域 ～～～～～～～～ & 106.40 & 43 & 69.50 & 28 & 86.52 & 35 & 103.53 & 42 \\
\hline 大溪水库西岸临湖岸坡 & 2.83 & 34 & 0.87 & 10 & 2.32 & 28 & 1.80 & 21 \\
\hline 大溪水库东岸临湖岸坡 & 4.66 & 24 & 2.52 & 13 & 4.19 & 22 & 3.53 & 18 \\
\hline 大溪水库上游水源涵养区 & 5.55 & 62 & 3.83 & 43 & 5.38 & 60 & 4.93 & 55 \\
\hline 沙河水库西岸临湖岸坡 & 8.15 & 31 & 5.15 & 19 & 7.60 & 29 & 6.76 & 25 \\
\hline 沙河水库东岸临湖岸坡 & 6.57 & 56 & 2.88 & 25 & 5.11 & 44 & 4. 19 & 36 \\
\hline 沙河水库上游水源涵养区 & 33.03 & 82 & 24.70 & 61 & 31.50 & 78 & 28.86 & 72 \\
\hline
\end{tabular}



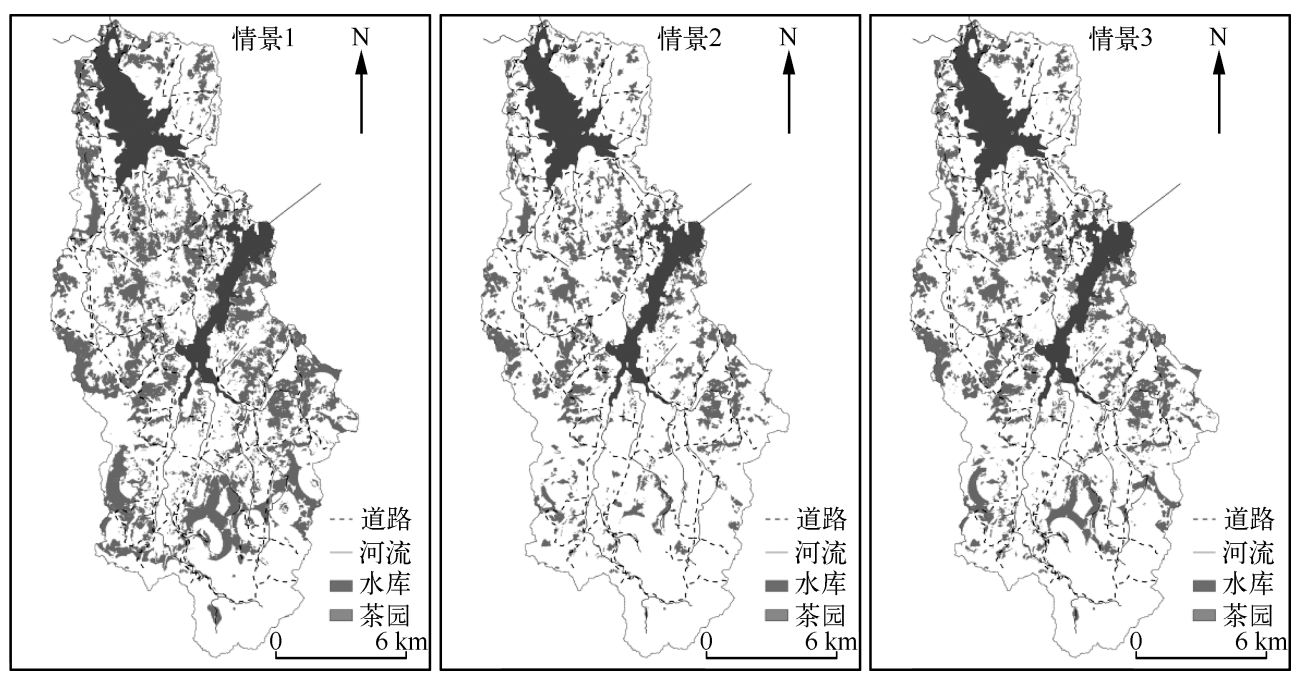

图 5 基于茶园开发 MLP 模拟模型的 2020 年不同情景下的茶园分布预测

Fig. 5 Tea plantation prediction model based on MLP neural network in 2020

\section{5 参考文献}

[1 ] 刘纪远,邓祥征. LUCC 时空过程研究的方法进展. 科学通报,2009,54(21):3251-3258.

[ 2 ] Hao HM , Ren ZY. Land use/land cover change ( LUCC) and eco-environment response to LUCC in farming-pastoral zone, China. Agricultural Sciences in China, 2009, 8(1) : 91-97.

[ 3 ] Xu HZ, Qu FT, Guo ZX. Dynamic changes and optimal allocation of arable land conversion in transition of Jiangsu Province. China Population, Resources and Environment, 2007,17 (5):54-58.

[ 4 ] Louisa JM, Jansen MBMF. Analysis of landcover/use change dynamics in Manica Province in Mozambique in a period of transition. Forest Ecology and Management, 2008 ,254 : 308-326.

[ 5 ] Lopez-Carr D, Davis J, Jankows et al. Space versus place in complex human-natural systems: Spatial and multi-level models of tropical land use and cover change (LUCC) in Guatemala. Ecological Modelling, 2012 ,229:64-75.

[ 6 ] Evans TP, Manire A, de Castro F. A dynamic model of household decision-making and parcel level landcover change in the eastern Amazon. Ecological Modelling,2001,143: 95-113.

[ 7 ] Miriam SW, Taylor VS. Modeling social and land-use/land-cover change data to assess driversof smallholder deforestation in Belize. Applied Geography,2010, 30: 329-342.

[8 ] 陈志强. 区域多尺度 LUCC 及空间数据库研究 [学位论文].福州:福建师范大学, 2006.

[ 9 ] 何春阳,史培军,陈 晋等. 北京地区土地利用/覆盖变化研究. 地理研究,2001,20(6):679-688.

[10] 刘纪远,张增祥,徐新良等. 21 世纪初中国土地利用变化的空间格局与驱动力分析. 地理学报, 2009,64 (12): 1411-1420.

[11］摆万奇,赵士洞. 土地利用变化驱动力系统分析. 资源科学,2001,23(3):39-41.

[12] 彭 建, 蔡运龙. LUCC 框架下喀斯特地区土地利用/覆被变化研究现状与展望. 中国土地科学, 2006, 20 (5): 48-53.

[13] Rao KS, Rekha P. Land use dynamics and landscape change pattern in a typical micro watershed in the mid elevation zone of central Himalaya, India. Agriculture, Ecosysyems and Environment, 2001, 86 :113-123.

[14] 张银辉,罗 毅, 刘纪远等. 灌区土地利用变化驱动因素分析一以内蒙古河套灌区为例. 资源科学, 2006, 28 (1): $81-86$.

[15] 吴宏安,蒋建军,周杰等. 西安城市扩张及其驱动力分析. 地理学报,2005,60(1):143-150.

[16] 李 明,李广杰, 张 文等. 基于卡方检验法对长白山龙门峰裂隙岩体统计均值区划分. 吉林大学学报: 地球科学 
版, $2012, \mathbf{4 2}(2): 449-453$.

[17］徐广才, 康慕谊, 李亚飞. 基于 MLP-ANN 与 Markov Chain 的土地利用变化预测方法一一锡林郭勒盟为例. 生态 环境学报,2010,19(10):2386-2392.

[18] Eastman JR. IDRSI Taiga Tutorial. Massachusetts: Clark Labs, 2009:270.

[16] 吴 洵. 茶园土壤管理与施肥技术:第 2 版. 北京:金盾出版社,2009.

[20 ] Li HM, Ma YX, Liu WJ et al. Soil changes induced by rubber and tea plantation establishment: Comparison with tropical rain forest soilin xishuangbanna, SW China. Environmental Management, 2012, 50 : 837-848.

[21] Liu ZA, Yang JP, Yang ZC. Effects of rainfall and fertilizer types on nitrogen and phosphorus concentrations in surface runoff from subtropical tea fields in Zhejiang, China. Nutrient Cycling in Agroecosystems, 2012, 93 : 297-307.

[22] 吴承龙,程 亮,王成庭等. 基于 GIS 的皖南山区茶叶种植适宜性评价. 农业网络信息, 2012,2: 27-32.

[23] 韩 莹, 李恒鹏, 聂小飞等. 太湖上游低山丘陵地区不同用地类型氮磷收支平衡特征. 湖泊科学, 2012,24 (6): 829-837.

[24] Li Y, Li CK, Tao JJ et al. Study on spatial distribution of soil heavy metals in Huizhou city based on BP-ANN modeling and GIS. Procedia Environmental Sciences, 2011, 10,1953- 1960.

[25] Plumb AP, Rowe RC, York P et al. Optimisation of the predictive ability of artificial neural network (ANN) models: A comparison of three ANN programsand four classes of training algorithm. European Journal of Pharmaceutical Sciences, 2005,25 : 395-405.

[26] 徐昔保,杨桂山, 李恒鹏. 太湖流域土地利用变化对净初级生产力的影响. 资源科学, 2011,33(10):1940-1947. 